\title{
КОМСОМОЛ — ЭТО НА ВСЮ ЖИЗНЬ
}

\author{
Т. И. Мелехина \\ Московский гуманитарный университет
}

Аннотация: В статье автор делится личной историей работы в комсомоле, анализирует роль комсомола в воспитании молодежи.

Ключевые слова: ВЛКСМ; комсомол; воспоминания; молодежь; история СССР

\section{KOMSOMOL IS FOREVER}

\author{
T. I. Melekhina \\ Moscow University for the Humanities
}

Abstract: The paper shares the author's personal experience of work in Komsomol and analyses the role of Komsomol in the education of youth.

Keywords: All-Union Leninist Young Communist League; Komsomol; reminiscence; youth; history of the USSR

Я долго думала над тем, стоит ли мне писать воспоминания о работе в комсомоле, кому они будут нужны? Но все больше и больше прихожу к мысли, что надо. Ведь моя активная жизненная позиция начиналась со школьного комсомола. Идет время, уходят люди - очевидцы и участники событий, творятся мифы, а хочется, чтобы остались страницы истории.

СССР давно прекратил свое существование, а вместе с ним - и Всесоюзный Ленинский коммунистический союз молодежи. Однако, для меня, как и для многих моих сверстников слово «комсомол» до сих пор значит очень многое и в первую очередь - молодость, энергию и настоящую дружбу. Писать о комсомоле в моей судьбе - значит вспомнить всю сознательную жизнь, поскольку с комсомолом связана почти вся моя общественная и профессиональная деятельность.

Память невольно переносит в те далекие годы, когда, «...молоды мы были, как искренне дружили, как верили в себя» и жизнь казалась прекрасной, счастливой и удивительной. 
Очень часто задают вопрос: что же дал вам комсомол? Звание комсомольца давало нам только одну привилегию, быть первым во всем - в учебе, в труде; всегда находиться на острие событий.

Вступление в комсомол было подготовлено пионерским детством: в те годы каждый пионер мечтал стать комсомольцем. В ряды комсомола вступила в 14 лет, когда училась в седьмом классе, написала заявление в школьный комитет, и уже потом прошла процедуру принятия в бюро Калининского райкома комсомола. В школе комсомол шефствовал над пионерами. Мы были вожатыми и отвечали за успеваемость в классе. Для этого над слабыми учениками шефствовали старшеклассники. Если подопечные комсомольцу ученики получали двойки, его могли пригласить на бюро класса, но не для наказания, а помощи. Комитет комсомола и совет школы решали все вопросы самоуправления. Ребята радиофицировали школу под руководством учителя физики. Вместе с учителями мы проводили диспуты, не боялись острых тем, например, диспут «Существует ли любовь с первого взгляда?» или по кинофильму «Красное и черное» по роману Стендаля. Каждый класс выпускал свою стенгазету, и общешкольная газета готовилась редколлегией школы. На всю жизнь запомнились вечера, посвященные творчеству Есенина, Ахматовой, Цветаевой. Школа была открыта для нас и в выходные, и в каникулы. Сколько было интересных и полезных дел: и зарницы для пионеров проводили, и работали в Подмосковных совхозах на уборке картошки-морковки, на овощных базах, посадили молоденькие березы, туристические слеты каждой весной - соревнования, песни, стихи и т. д.

После окончания Московского химико-технологического техникума Нефтехимпрома СССР, работала инженером лаборатории в тресте Мосстрой № 16, где была избрана секретарем комитета комсомола, членом горкома комсомола города Москвы. В составе делегации горкома комсомола города Москвы участвовала в IX Всемирным фестивале молодежи и студентов, который проходил с 28 июля по 6 августа 1968 года в Болгарии. В то время съездить за границу было совсем непросто. Прежде всего пришлось заполнить соответствующие анкеты, сделать прививки от различных болезней, для обмена валюты можно было взять только 40 рублей, две бутылки «Московской» водки для организации встреч с иностранными делегациями. Прилетели в Варну, расположенную на берегу Черного моря с курортами «Солнечный берег», «Золотые пески». Здесь для нас были организованы экскурсии. С 27 июля по 2 августа 1968 года нашу делегацию разместили в Международном молодежном лагере «Приморское» недалеко от города Бургаса. Жили по четыре человека в отдельных бунгало со всеми удобствами. В лагере проводились встречи делегаций, спортивные соревнования по пляжному волейболу, борьбе, художественной самодеятельности. 2 августа 
Научные труды Московского гуманитарного университета 2018 № 6

переехали в город Пловдив. Закрытие фестиваля состоялось 6 августа 1968 года на стадионе Софии. Что осталось в душе и памяти? Любовь болгар к русским Она проявлялась во всей стране, где мы появлялись, где звучала русская речь.

Осенью 1968 года поступила учиться на химико-металлургический факультет Московского инженерно-экономического института имени С. Орджоникидзе, где была принята в партию, избрана секретарем комсомольского бюро факультета, стала Ленинской стипендианткой. Главная задача, стоявшая перед нами - получить хорошие знания и стать хорошими специалистами. Студенческие годы незабываемы. Это и факультетский хор, в котором участвовали даже студенты-юноши, и фестивали. Наш факультет дважды выходил победителем фестиваля и джаз группа «Оранжевые велосипеды». Вечера отдыха привлекали молодежь из других вузов. Зал на 1000 человек не вмещал всех желающих. Были летние стройотряды. Мне как секретарю приходилось вникать и в семейные проблемы студентов. А общежитие нашего института не раз выходило победителем во Всесоюзном соревновании среди студенческих общежитий. Чему научил комсомол меня в институте? Прежде всего, умению понимать сверстников, руководить комитетом факультета и бюро групп. Я помню всех своих коллег по комсомолу. Эту дружбу храню в своем сердце. Я научилась выступать с трибуны без бумажки. Все эти навыки помогли мне в профессиональном росте. После окончания института, работая инженером - экономистом в ГВЦ ГОССНАБА СССР продолжала активно участвовать в жизни комсомольской организации. В 1971 г. была избрана секретарем комсомольской организации ГВЦ ГОССНАБА СССР. С этого времени комсомольская работа для меня из общественной становится профессиональной на период до 1978 года, это годы овладения организаторскими навыками в процессе проведения больших массовых мероприятий с молодежью, серьезная школа жизни. Однако, меня влекла научно-педагогическая деятельность и преподавательская работа, поэтому в 1978 году я поступила в очную аспирантуру Московского института управления (бывший МИЭИ имени С. Орджоникидзе), продолжая активно участвовать в жизни комсомольской организации вуза. По окончании аспирантуры занимаюсь научной и педагогической деятельностью.

О комсомоле, его месте и роли в воспитании молодежи в советское время я знаю и могу судить достаточно объективно. Во-первых, комсомол способствовал сформировал мои политические взгляды и нравственные убеждения, расширил мой политический кругозор, развил потребность в систематическом чтении газет, привил вкус к политической информации. Во-вторых, развил мои организаторские способности. В комсомоле я прошла практическую школу организации и сплочения коллектива, овладе- 
ла искусством ставить в работе цели для себя и руководимого мною коллектива, добиваться достижения их, не останавливатьлся на достигнутом. В-третьих, комсомол научил самокритично оценивать свою деятельность и взаимоотношения с окружающими людьми, уважать мнения оппонентов. Научил демократическому стилю руководства.

Считаю, что моему поколению очень повезло. Комсомол не только заложил в сознание правильные ценности и установки, но и подарил друзей на всю жизнь. Удивительно, но тот запал и тот задор, который был у нас в комсомольские годы, никуда не ушел.

Сейчас много говорят о здоровом образе жизни. В те годы об этом говорили меньше, а делали все возможное для занятий физкультурой и спортом. Проходили зимние и летние спартакиады по многим видам спорта. Отмечались все ноябрьские, новогодние и майские праздники. Я очень любила демонстрации 7 ноября и 1 мая. Тогда не оценивалось все деньгами, мы жили делами, встречами, дружбой, событиями.

Сегодня анализируя свою комсомольскую юность, с глубокой убежденностью могу подтвердить, комсомол был уникальной общественно-политической организацией. В истории не было равной ему ни по масштабам, ни по общественной значимости молодежной организации в решении социальных, экономических и политических задач общества.

В настоящее время в нашей стране набирает темпы воллонтерская работа, и я безмерно радуюсь и горжусь этим. Молодые люди оказывают помощь ветеранам, инвалидам. Значит, традиции комсомола живы и сейчас! А это подтверждение тому, что комсомол будет жить. В масштабах страны имело огромное значение участие комсомола начиная с гражданской войны в новостройках индустриализации, в подъеме целины, в строительстве БАМа и других новостроек. Подвиги пионеров и комсомольцев в годы Великой Отечественной войны учили нас любить Родину. За эти заслуги на знамени ВЛКСМ засияли пять орденов!

Прошлое еще долго будет держаться в памяти тех, кто жил в советское время, напоминать о себе и новым поколениям молодежи, стучаться в их дверь названиями улиц, площадей, памятниками культуры.

Комсомол оставил после себя немало великолепных памятников, построенных на собственные средства, заработанные на субботниках и воскресниках. Есть улицы, названные в честь комсомольцев, оставивших свой яркий след в истории комсомола. Почти в каждом городе и крупном поселении имеется своя Комсомольская площадь или Комсомольская улица.

Сколько было по инициативе комсомола построено стадионов, спортивных площадок, проведено спортивных соревнований, праздников, туристических слетов, олимпиад, подготовлено тренеров и инструкторов-об- 
Научные труды Московского гуманитарного университета 2018 № 6

щественников по различным видам спорта! В памяти до сих пор остаются: сдача норм на значок ГТО, массовые лыжные старты на приз газеты «Пионерская правда», детские спортивные клубы «Кожаный мяч», «Золотая шайба», «Белая ладья», «Веселый дельфин», военно-спортивные игры «Зарница» и «Орленок»-реальные, рожденные и поддержанные комсомолом дела. И для каждой категории юношей и девушек находилось свое дело. Для рабочей молодежи - конкурсы профессионального мастерства «А ну ка девушки», научно-техническое творчество, советы молодых специалистов, «Комсомольский прожектор». Для пионеров и школьников - научные общества, станции юных техников и юных натуралистов, геологические походы. Для студентов - стройотряды. И как эстафета, переданная современному поколению патриотов России - начатые комсомолом экспедиции с целью найти и захоронить останки воинов, погибших в годы Великой Отечественной войны.

Комсомол был первопроходцем, строителем и воином, школой жизни, мужества и героизма. Он вел молодежь туда, где, прежде всего, нужны были надежные и крепкие руки, энергия и задор юности. На страницах истории комсомола не только ударные стройки и войны, энтузиазм и трудовой порыв в годы первых пятилеток.

Было и нечто другое, ибо в каждом городе, в каждой деревне решалась своя историческая задача. И совсем неважно, сколько было комсомольцев - тысячи или всего три человека. Был такой лозунг: «Если тебе комсомолец имя - имя крепи делами своими!» Вспомним ликвидацию безграмотности, вечерние школы и рабфаки, избы-читальни, «Синюю блузу», театры рабочей молодежи, борьбу с детской беспризорностью, пионерские отряды. Это и был комсомол, его светлая линия. Кто сегодня может сказать, что такое «чтецкая повинность»? А ведь было и такое в нашей неграмотной стране. Люди, не умевшие читать, хотели знать новости, знать, чем наполнена жизнь, что делается в стране. И им читали эти новости другие, грамотные и умевшие читать. Их называли культармейцами и были этими культармейцами комсомольцы. Это они читали людям газеты вслух, а чтобы чтение сухих официальных сводок было интересным и образным, придумали «живую газету», которую назвали «Синяя блуза». И так во всем - в культуре, науке, спорте, воспитании детей - бралась одна высота за другой.

Комсомол - это целая эпоха в жизни нашей многонациональной Родины и неотъемлемая часть развития общества. Славные вехи его становления неразрывно связаны с великими и порой драматическими этапами истории нашей страны. Молодое племя послереволюционной России стремительно возводило новый мир, искренне веря в его светлое будущее. Романтики и мечтатели, они, словно одержимые великим предназначением, творили ге- 
роическую историю - наперекор всему яростно стремились вперед, преодолевая неистовое стремление и коварство недругов, теряя в борьбе верных друзей и соратников. Им выпала нелегкая миссия возводить первое в мире государство рабочих и крестьян, испытывая порой на этом тернистом пути жгучую горечь из-за тактических ошибок и разочарования от неудавшихся реформ. Тем не менее, никакие сегодняшние ревизионистские попытки отдельных исследователей не способны отрицать очевидное - это была эпоха великих свершений. Государство, где справедливость и уважение к личности стояли на первом месте, а мерилом достоинства и уважения к человеку был его труд. Самые дерзновенные достижения в СССР: борьба с разрухой и безграмотностью, индустриализация и освоение Сибири, строительство Магнитки, Днепрогэса, ЧТЗ, Московского метро, БАМа, Победа над фашизмом, освоение целины и космоса, строительство Троицкой ГРЭС и тысячи других великих дел, состоялись при созидательном участии ВЛКСМ - признанном авангарде советской молодежи. Пытливый ум, энтузиазм и жажда созидания комсомольцев вдохновлялись непоколебимой верой в творчество высших общественных идеалов и стремлением служить народу. Не их вина, воспитанных в духе социальной справедливости, что коварным разрушителям СССР и псевдодемократам горбачевско-ельцинского периода (и обожаемой на Западе пятой колонне «русской интеллигенции») удалось, пробравшись в руководство, внести раскол в ее ряды и предать их идеалы.

ВЛКСМ - это уникальный опыт массового вовлечения молодежи в общественный творческий процесс. Его история, невзирая ни на что, остается незабываемой страницей молодежного движения в России.

Дата поступления: 30.08.2018 2.

Мелехина Татьяна Игнатьевна - кандидат экономических наук, доцент кафедры статистики, маркетинга и бухгалтерского учета Московского гуманитарного университета. Адрес: 111395, Россия, г. Москва, ул. Юности, д. 5. Тел.: +7 (499) 374-58-60. Эл. адрес: kafstat@mosgu.ru

Melekhina Tatyana Ignatyevna, Candidate of Economics, AssociateProfessor, Department of Statistics, Marketing, and Accounting, Moscow University for the Humanities. Postal address: 5, Yunosti St., Moscow, Russian Federation, 111395. Tel.: +7 (499) 374-58-60. E-mail: kafstat@mosgu.ru 


\section{Для цитирования:}

Мелехина Т. И. Комсомол - это на всю жизнь [Электронный ресурс] // Научные труды Московского гуманитарного университета. 2018. № 6. URL: http://journals.mosgu.ru/trudy/article/view/839 (дата обращения: дд.мм.гг.). DOI: $10.17805 /$ trudy.2018.6.8 